\title{
Statyba
}

\section{STRENGTH AND SAFETY OF SLAB-WALL JOINTS OF REINFORCED CONCRETE BUILDINGS UNDER GRAVITY AND LATERAL LOADS}

Alg. Kudzys \& Alg. Kudzys

To cite this article: Alg. Kudzys \& Alg. Kudzys (1996) STRENGTH AND SAFETY OF SLAB-WALL JOINTS OF REINFORCED CONCRETE BUILDINGS UNDER GRAVITY AND LATERAL LOADS, Statyba, 2:8, 45-51, DOI: 10.1080/13921525.1996.10590171

To link to this article: https://doi.org/10.1080/13921525.1996.10590171

Published online: 01 Nov 2012.

Submit your article to this journal $₫$

Џلll Article views: 418 


\section{STRENGTH AND SAFETY OF SLAB-WALL JOINTS OF REINFORCED CONCRETE BUILDINGS UNDER GRAVITY AND LATERAL LOADS}

\section{Alg. Kudzys}

\section{Introduction}

This article considers structural safety of ordinary slab-wall joints in cast-in-situ reinforced concrete buildings with thin-walled and thin-slabed bearing members. These members are under action effects caused by gravity and lateral (wind or seismic) loads. Bending moments of alternating sign need double reinforcement for slabs and walls. The joints designed on the basis of strength without considering special ductility requirements by analogy with beam-column joints [1].

An influence of out-plane lateral forces on slab-wall joints is not yet sufficiently investigated. It is known that an endurance of slab-wall joints, i.e. their long-term safety and durability under reiterated episodic lateral loads of great intensity is closely connected with strength of joint core. Joint safety analysis can be based on the assumption that its core is a free concrete member with compressive, tensile and shear forces acting on its critical section adjacent to the slab and wall members with double reinforcement.

If bending moment reversals can cause stress reversals in the slab and wall longitudinal reinforcement and for composite (precast and cast-in-situ) floor slabs, the critical section of slabs concurs with a face of the confined wall core, i. e. the design depth of the wall is $h^{\prime}$ (Fig. 1).

Research results [2, 3] have shown that a loss of bearing resistance of slab-wall joints subjected to large out-plane lateral loading may occur due to brittle failure under compression of concrete diagonal strut of a joint core. It leads to a loss of overall stability of bearing structures. Therefore, a core belongs to high-reliability member of slab-wall joints, which structural safety must be checked in design procedures. a)

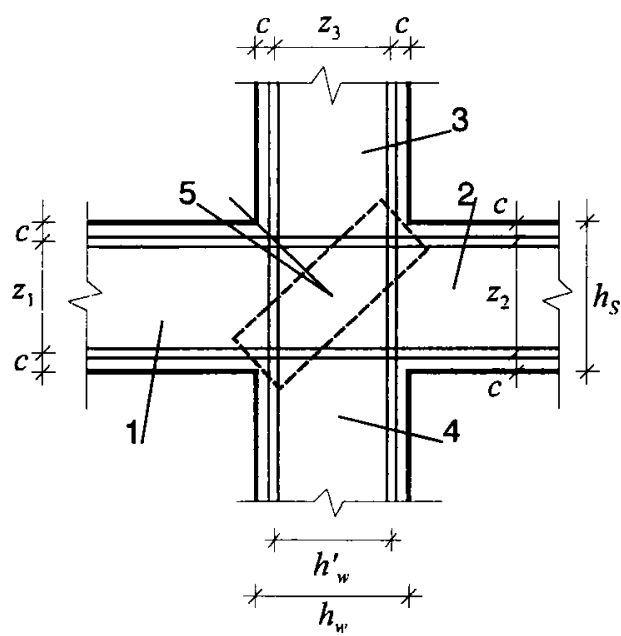

b)



Fig. 1. Elevation of slab-wall joints with floor slabs cast on split moulds (a) and precast reinforced concrete slabs (b): 1 and 2 - floor slabs; 3 and 4 - wall members; 5 - joint core; 6 - precast slabs 

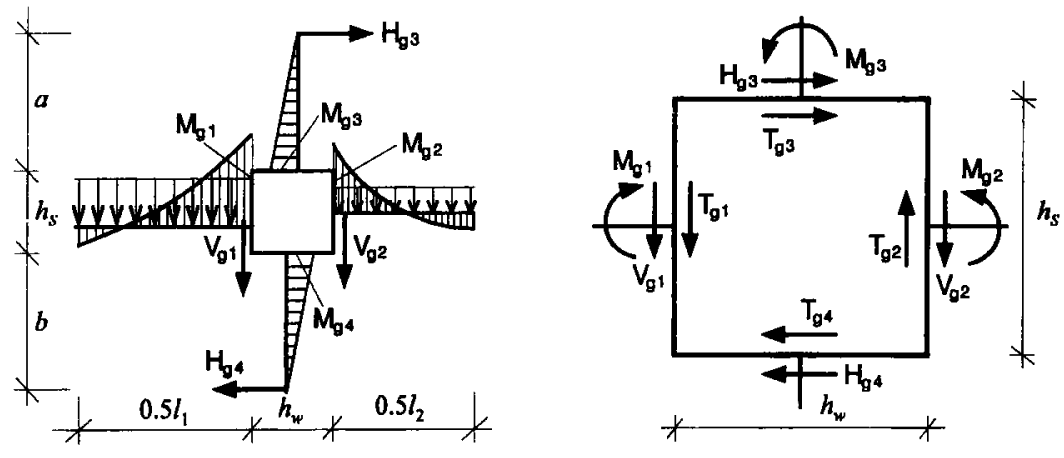

b)
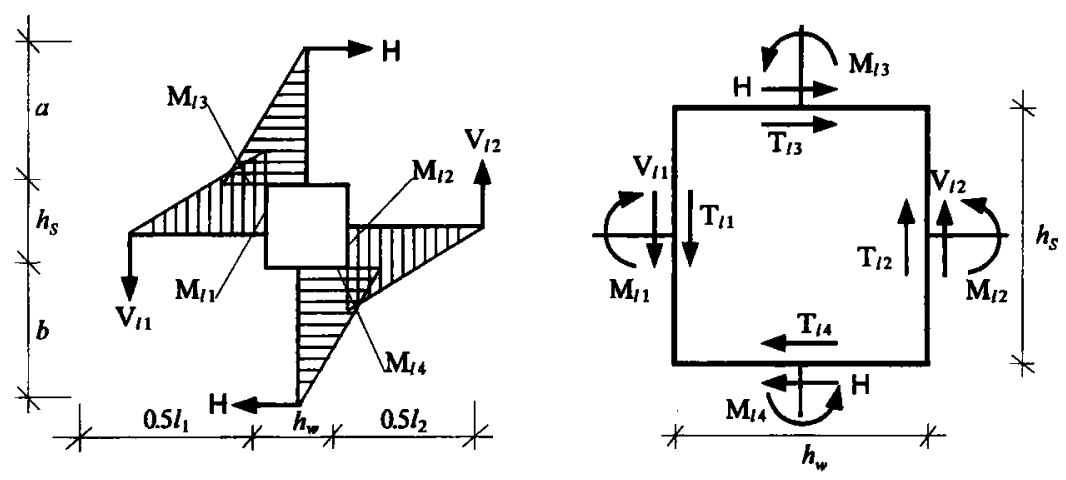

Fig. 2. Acting bending moments and shear forces in slabs, walls and their joint core caused by gravity (a) and lateral (b) loads

\section{Joint core shear forces}

From Fig. 2 the action of bending moments and shear forces on a core of slab-wall joints is evident. The moments and forces required to keep the slab-wall joints in equilibrium and their numerical values are calculated by the following equations:

$$
\begin{gathered}
M_{g 1}=\beta_{M} p_{1} l_{1}^{2} ; M_{g 2}=\beta_{M} p_{2} l_{2}^{2} ; \\
M_{g 3}=\frac{b \beta_{M}}{a+b}\left(p_{1} l_{1}^{2}-p_{2} l_{2}^{2}\right) ; \\
M_{g 4}=\frac{a \beta_{M}}{a+b}\left(p_{1} l_{1}^{2}-p_{2} l_{2}^{2}\right) ; \\
V_{g 1}=\beta_{Q} p_{1} l_{1} ; V_{g 2}=\beta_{Q} p_{2} l_{2} \\
H_{g 3}=\frac{b \beta_{M}}{a(a+b)}\left(p_{1} l_{1}^{2}-p_{2} l_{2}^{2}\right) ; \\
H_{g 4}=\frac{a \beta_{M}}{b(a+b)}\left(p_{1} l_{1}^{2}-p_{2} l_{2}^{2}\right) ;
\end{gathered}
$$

$$
\begin{gathered}
M_{l 1}=H l_{2}(a+b) /\left(l_{1}+l_{2}\right) ; \\
M_{l 2}=H l_{1}(a+b) /\left(l_{1}+l_{2}\right) ; \\
M_{l 3}=H a ; M_{l 4}=H b ; \\
V_{l 1}=H \frac{2 l_{2}(a+b)}{l_{1}\left(l_{1}+l_{2}\right)} \\
V_{l 2}=H \frac{2 l_{1}(a+b)}{l_{2}\left(l_{1}+l_{2}\right)} \\
V_{w 3}=V_{w 4}=H .
\end{gathered}
$$

Here the coefficients $\beta_{M}$ and $\beta_{Q}$ evaluate the geometry of slabs and redistribution of gravity actions effects due to concrete creep and settlement of foundation; $H$ is the joint horizontal action effect caused by lateral loads.

The statistical estimates (means and variances) of probability distribution of the shear forces of joint core 
caused by gravity and lateral loads (Fig. 2) are calculated by formulae:

$$
\begin{aligned}
& T_{g 1 m}=\left(M_{g 1 m}-M_{g 2 m}\right) / h_{w m}+V_{g 1 m} ; \\
& \mathrm{s}^{2} T_{g 1}=\frac{1}{h_{w}^{2}}\left(\mathrm{~s}^{2} M_{g 1}+\mathrm{s}^{2} M_{g 2}\right)+ \\
& +\frac{s^{2} h_{w}}{h_{w}^{4}}\left(M_{g 1}^{2}+M_{g 2}^{2}\right)+s^{2} V_{g 1} \\
& T_{g 2 m}=\left(M_{g 1 m}-M_{g 2 m}\right) / h_{w m}+V_{g 2 m} \\
& \mathrm{~s}^{2} T_{g 2}=\frac{1}{h_{w}^{2}}\left(\mathrm{~s}^{2} M_{g 1}+\mathrm{s}^{2} M_{g 2}\right)+ \\
& +\frac{s^{2} h_{w}}{h_{w}^{4}}\left(M_{g 1}^{2}+M_{g 2}^{2}\right)+s^{2} V_{g 2} \\
& T_{g 3 m}=\left(M_{g 3 m}+M_{g 4 m}\right) / h_{s m}+H_{g 3 m} \\
& \mathrm{~s}^{2} T_{g 3}=\frac{1}{h_{s}^{2}}\left(\mathrm{~s}^{2} M_{g 3}+\mathrm{s}^{2} M_{g 4}\right)+ \\
& +\frac{s^{2} h_{s}}{h_{s}^{4}}\left(M_{g 3}^{2}+M_{g 4}^{2}\right)+s^{2} H_{g 3} ; \\
& T_{g 4 m}=\left(M_{g 3 m}+M_{g 4 m}\right) / h_{s m}+H_{g 4 m} \\
& \mathrm{~s}^{2} T_{g 4}=\frac{1}{h_{s}^{2}}\left(\mathrm{~s}^{2} M_{g 3}+\mathrm{s}^{2} M_{g 4}\right)+ \\
& +\frac{s^{2} h_{s}}{h_{s}^{4}}\left(M_{g^{3}}^{2}+M_{g^{4}}^{2}\right)+s^{2} H_{g 4} ; \\
& T_{l 1 m}=\left(M_{l 1 m}+M_{l 2 m}\right) / h_{w m}+V_{l 1 m} \\
& \mathrm{~s}^{2} T_{l 1}=\frac{1}{h_{w}^{2}}\left(\mathrm{~s}^{2} M_{l 1}+\mathrm{s}^{2} M_{l 2}\right)+ \\
& +\frac{\mathrm{s}^{2} h_{w}}{h_{w}^{4}}\left(M_{l 1}^{2}+M_{l 2}^{2}\right)+\mathrm{s}^{2} V_{l 1} \\
& T_{l 2 m}=\left(M_{l 1 m}+M_{l 2 m}\right) / h_{w m}+V_{l 2 m} \text {; } \\
& \mathrm{s}^{2} T_{l 2}=\frac{1}{h_{w}^{2}}\left(\mathrm{~s}^{2} M_{l 1}+\mathrm{s}^{2} M_{l 2}\right)+ \\
& +\frac{s^{2} h_{w}}{h_{w}^{4}}\left(M_{l 1}^{2}+M_{l 2}^{2}\right)+s^{2} V_{l 2} ; \\
& T_{l 3 m}=T_{l 4 m}=\left(M_{l 3 m}+M_{l 4 m}\right) / h_{s m}+H_{m} ; \\
& \mathrm{s}^{2} T_{l 3}=\mathrm{s}^{2} T_{l 4}=\frac{1}{h_{s}^{2}}\left(\mathrm{~s}^{2} M_{l 3}+\mathrm{s}^{2} M_{l 4}\right)+ \\
& +\frac{s^{2} h_{s}}{h_{s}^{4}}\left(M_{l 3}^{2}+M_{l 4}^{2}\right)+s^{2} H \text {. }
\end{aligned}
$$

According to data $[4,5]$, for cast-in-situ slab and walls the design variances of probability distribution of geometrical dimensions can be accepted as follows:

$s^{2} h_{s}=s^{2} h_{w}=1 \mathrm{~cm}$ in height of member cross-section;

$\mathrm{s}^{2} \mathrm{c}=0.25 \mathrm{~cm}^{2}$ in thickness of concrete conditional cover;

$\mathrm{s}^{2} \mathrm{~d}=0.25 \mathrm{~cm}^{2}$ in thickness of precast thin slabs used instead of split moulds.

\section{Joint core compression forces}

Compression forces of joint core are caused by wall axial forces and bending moment acting on its vertical and horizontal estimates of compression forces depend both on probability distribution of these action effects and arms of inner couples (Fig. 3).

The means and variances of the arms of inner couples are:

$$
\mathrm{z}_{1 \mathrm{~m}}=\mathrm{z}_{2 \mathrm{~m}}=\mathrm{h}_{\mathrm{sm}}-2 \mathrm{c}_{\mathrm{m}} ; \mathrm{s}^{2} \mathrm{z}_{1}=\mathrm{s}^{2} \mathrm{z}_{2}=\mathrm{s}^{2} \mathrm{~h}_{\mathrm{s}}+4 \mathrm{~s}^{2} \mathrm{c} ;
$$

for pure cast-in-situ floor slabs, and

$$
\begin{gathered}
\mathrm{z}_{1 \mathrm{~m}}=\mathrm{h}_{\mathrm{sm}}-\mathrm{c}_{\mathrm{m}}-0.5 \mathrm{~d}_{\mathrm{m}} ; \mathrm{s}^{2} \mathrm{z}_{1}=\mathrm{s}^{2} \mathrm{~h}_{\mathrm{s}}+\mathrm{s}^{2} \mathrm{c}+0.25 \mathrm{~s}^{2} \mathrm{~d} ; \\
\mathrm{z}_{2 \mathrm{~m}}=\mathrm{h}_{\mathrm{sm}}-2 \mathrm{c}_{\mathrm{m}}-\mathrm{d}_{\mathrm{m}} ; \mathrm{s}^{2} \mathrm{z}_{2}=\mathrm{s}^{2} \mathrm{~h}_{\mathrm{s}}+4 \mathrm{~s}^{2} \mathrm{c}+\mathrm{s}^{2} \mathrm{~d}
\end{gathered}
$$

for composite floor slabs.

The statistical estimates for wall members are:

$$
\begin{aligned}
& z_{3 m}=0.5 h_{w m}-c_{m}+M_{3 m} / N_{g 3 m} ; \\
& \mathrm{s}^{2} z_{3}=0.25 \mathrm{~s}^{2} h_{w}+\mathrm{s}^{2} c+\mathrm{s}^{2} M_{3} / N_{g 3 m}^{2}+ \\
& +\left(M_{3 m} / N_{g 3 m}^{2}\right)^{2} \mathrm{~s}^{2} N_{g 3} \\
& z_{4 m}=0.5 h_{w m}-c_{m}+M_{4 m} / N_{g 4 m} \\
& \mathrm{~s}^{2} z_{4}=0.25 \mathrm{~s}^{2} h_{w}+\mathrm{s}^{2} c+\mathrm{s}^{2} M_{4} / N_{g 4 m}^{2}+ \\
& +\left(M_{4 m} / N_{g 4 m}^{2}\right)^{2} \mathrm{~s}^{2} N_{g 4}
\end{aligned}
$$

where $M_{3}=M_{g 3}=M_{13}$ and $M_{4}=M_{g 4}+M_{14}$ are the sums of bending moments, and $\mathrm{N}_{\mathrm{g} 3}$ and $\mathrm{N}_{\mathrm{g} 4}$ are the acting axial forces in upper and lower wall members, respectively. The axial forces in slab and wall members caused by lateral forces can be neglected due to their small values.

The joint core compression forces $D_{i}$ (Fig. 3) consist of two components $\mathrm{D}_{\mathrm{gi}}$ and $\mathrm{D}_{\mathrm{li}}$ caused by gravity and lateral loads, respectively. The means and variances of 
a)

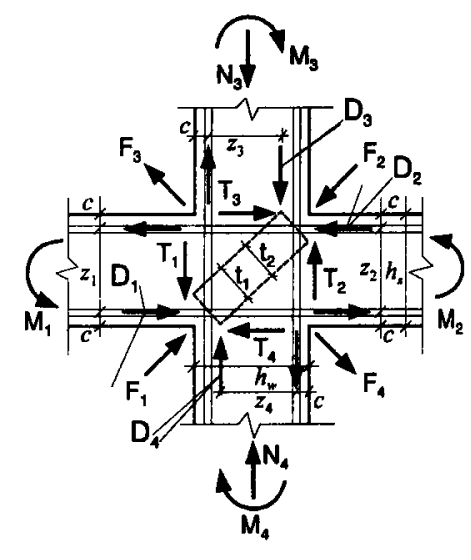

b)

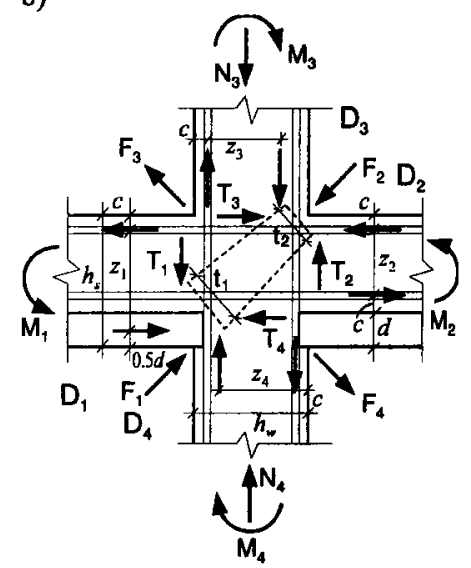

Fig. 3. Inner forces in joint core of slab-wall connections with pure cast-in-situ (a) and composite (b) floor slabs

probability distribution of these components are calculated by following formulae :

$$
\begin{gathered}
D_{g 1 m}=M_{g 1 m} / z_{1 m} \\
s^{2} D_{g 1}=s^{2} M_{g 1} / z_{1 m}^{2}+s^{2} z_{1} M_{g 1 m}^{2} / z_{1 m}^{4} \\
D_{g 2 m}=M_{g 2 m} / z_{2 m} \\
\mathrm{~s}^{2} D_{g 2}=\mathrm{s}^{2} M_{g 2} / z_{2 m}^{2}+\mathrm{s}^{2} z_{2} M_{g 2 m}^{2} / z_{2 m}^{4} \\
D_{g 3 m}=\left[M_{g 3 m}+N_{g 3 m}\left(05 h_{w m}-c_{m}\right)\right] / z_{3 m} \\
\mathrm{~s}^{2} D_{g 3}=\sum_{i=1}^{5}\left(\frac{\partial D_{g 3}}{\partial \xi_{i}}\right)_{m}^{2} \mathrm{~s}^{2} \xi_{i} ; \xi_{i}=M_{g 3} ; N_{g 3} ; h_{w} ; c ; z_{3} ; \\
D_{g 4 m}=\left[M_{g 4 m}+N_{g 4 m}\left(0.5 h_{w m}-c_{m}\right)\right] / z_{4 m} \\
\mathrm{~s}^{2} D_{l 3}=\mathrm{s}^{2} M_{l 3} / z_{3 m}^{2}+\mathrm{s}^{2} z_{3} M_{l 3 m}^{2} / z_{3 m}^{4} \\
\mathrm{~s}^{2} D_{g 4}=\sum_{i=1}^{5}\left(\frac{\partial D_{g 4}}{\partial \xi_{i}}\right)_{m}^{2} \mathrm{~s}^{2} \xi_{i} ; \xi_{i}=M_{g 4} ; N_{g 4} ; h_{w} ; c ; z_{4} ;( \\
D_{l 1 m}=M_{l 1 m} / z_{1 m} \\
\mathrm{~s}^{2} D_{l 1}=\mathrm{s}^{2} M_{l 1} / z_{1 m}^{2}+\mathrm{s}^{2} z_{1} M_{l 1 m}^{2} / z_{1 m}^{4} \\
D_{l 2 m}=M_{l 2 m} / z_{2 m}
\end{gathered}
$$

$$
\begin{gathered}
D_{l 4 m}=M_{l 4 m} / z_{4 m} \\
\mathrm{~s}^{2} D_{l 4}=\mathrm{s}^{2} M_{l 4} / z_{4 m}^{2}+\mathrm{s}^{2} z_{4} M_{l 4 m}^{2} / z_{4 m}^{4} .
\end{gathered}
$$

\section{Diagonal strut forces}

The diagonal cracks in a joint core are caused by tensile force resultants $F_{3}$ and $F_{4}$ (Fig. 3). Concrete member between diagonal cracks in the core centre becomes a conditional compression strut. An analysis of structural safety of concrete joint core can be based on the failure mechanism of this strut, which compressive forces $F_{1}$ and $\mathrm{F}_{2}$ are caused by gravity and lateral loads [6].

If the resultant forces $F_{g 1}$ and $F_{g 2}$ are caused by gravity loads, their means of probability distribution can be expressed by the equations :

$$
\begin{aligned}
& F_{g 1 m}=\left[\left(2 D_{g 1 m}+T_{g 4 m}\right)^{2}+\left(2 D_{g 4 m}+T_{g 1 m}\right)^{2}\right]^{1 / 2} \\
& F_{g 2 m}=\left[\left(2 D_{g 2 m}+T_{g 3 m}\right)^{2}+\left(2 D_{g 3 m}+T_{g 2 m}\right)^{2}\right]^{1 / 2} .
\end{aligned}
$$

For revealing statistical estimates of probability distribution of compressive forces $F_{11}$ and $F_{12}$ caused by lateral loads, the following equations are used :

$$
\begin{aligned}
& F_{w 1 m}=\left[\left(2 D_{l 1 m}+T_{l 4 m}\right)^{2}+\left(2 D_{l 4 m}+T_{l 1 m}\right)^{2}\right]^{1 / 2} \\
& F_{w 2 m}=\left[\left(2 D_{l 2 m}+T_{l 3 m}\right)^{2}+\left(2 D_{l 3 m}+T_{l 2 m}\right)^{2}\right]^{1 / 2}
\end{aligned}
$$


In both loading cases, the variances of resultant forces can be calculated by the equation :

$$
\begin{aligned}
& \mathbf{s}^{2} F=\sum_{i=1}^{4}\left(\frac{\partial F}{\partial \xi_{i}}\right)_{m}^{2} \mathrm{~s}^{2} \xi_{i}+ \\
& +\sum_{i} \sum_{j}\left(\frac{\partial F_{g}}{\partial \xi_{i}}\right)_{m}\left(\frac{\partial F_{g}}{\partial \xi_{j}}\right)_{m} \operatorname{cov}\left(\xi_{i} ; \xi_{j}\right)
\end{aligned}
$$

Here $s^{2} \xi_{i}$ denotes the variance of probability distribution of random vector $\xi_{i}$ representing the compressive force $\mathrm{D}_{\mathrm{i}}$ or shear force $\mathrm{T}_{\mathrm{i}}$;

$\operatorname{cov}\left(\xi_{i} ; \xi_{j}\right)=\left(\frac{\partial \xi_{i}}{\partial \eta} \frac{\partial \xi_{j}}{\nabla \eta}\right)_{m} \mathrm{~s}^{2} \eta$ is the cross covariance of two random vectors $\xi_{\mathrm{i}}$ and $\xi_{\mathrm{j}}$, where $\eta$ is the random argument representing gravity or lateral loads.

\section{Diagonal strut resistance}

The compression resistance of concrete strut of joint core is closely connected with statistical estimates of the strut thickness $t$ and its concrete resistance $f_{c}$.

On the basis of research data [5], the distance between diagonal concrete and just the same the thickness of the conditional diagonal strut is

$$
t=0.4\left(z_{s}^{2}+z_{w}^{2}\right)^{1 / 2}
$$

where $z_{s}$ and $z_{w}$ are the arms of inner couple of slab and wall members, respectively.

Therefore, the means and variances of probability distribution of thickness $t_{1}$ and $t_{2}$ are :

$$
\begin{gathered}
t_{1 m}=0.4\left(z_{1 m}^{2}+z_{4 m}^{2}\right)^{1 / 2} \\
s^{2} t_{1}=0.16\left(z_{1 m}^{2} \mathbf{s}^{2} z_{1}+z_{4 m}^{2} \mathbf{s}^{2} z_{4}\right) /\left(z_{1 m}^{2}+z_{4 m}^{2}\right) \\
t_{2 m}=0.4\left(z_{2 m}^{2}+z_{3 m}^{2}\right)^{1 / 2} \\
\mathbf{s}^{2} t_{2}=0.16\left(z_{2 m}^{2} \mathbf{s}^{2} z_{2}+z_{3 m}^{2} \mathbf{s}^{2} z_{3}\right) /\left(z_{2 m}^{2}+z_{3 m}^{2}\right)
\end{gathered}
$$

where $z_{i m}$ and $s^{2} z_{i}$ are estimates by (23)...(28).

According to reference [4], the coefficient of variation of the concrete compression strength $\delta f_{c}$ depends not only on concrete type and strength but also on concrete mix consistency and quality, its production and casting process culture. For cast-in-situ normal concrete the coefficient $\delta f_{c}=6 . .20 \%$. In the case of average quality of erection culture of reinforced concrete structures the design coefficient $\delta \mathrm{f}_{\mathrm{c}} \approx 13 \%$.

The slab-wall connections of reinforced concrete structures subjected to intensive impact loads may be analyzed taking into account an increase in strength of materials. However, here one should not forget the increase in variance of probability distribution that may be increased considerably. It practically allows to consider the usual estimates of joint core mechanical parameters.

The estimates of probability distribution of the compression resistance of diagonal structure:

$$
\begin{gathered}
R_{1 m}=b t_{1 m} f_{c m} ; \\
\mathbf{s}^{2} R_{1}=\left(b t_{1 m}\right)^{2} \mathbf{s}^{2} f_{c}+\left(b f_{c m}\right)^{2} \mathbf{s}^{2} t_{1} ; \\
R_{2 m}=b t_{2 m} f_{c m} ; \\
\mathbf{s}^{2} R_{2}=\left(b t_{2 m}\right)^{2} \mathbf{s}^{2} f_{c}+\left(b f_{c m}\right)^{2} \mathbf{s}^{2} t_{2},
\end{gathered}
$$

where $b$ is the design width of the slab and wall members; $f_{c m}$ and $\mathbf{s}^{2} f_{c}$ are estimates of concrete compression strength.

\section{Structural safety index}

The effect of random in nature lateral loads on probabilistic reliability of structures is analyzed using statistics of the extreme distribution law of type I or II [7, 8]. However, the effect of maximum stochastically independent lateral loads can be modelled by discrete nonhomogenous Poisson process. In this case the method of limit random effects leads to simplification of analysis procedure and structural safety assessment of slab-wall joints [7]. This method excludes any estimation of structural failure due to human errors.

The efficiency of slab-wall joint core at the cut $k$ of non-stationary stochastic sequence can be expressed by the random process performance function

$$
Z_{k}=R_{k}-F_{g k}-F_{l k}=F_{\text {lim }, k}-F_{l k},
$$

where $R_{k}$ is the strut compression resistance; $F_{g k}$ and $F_{l k}$ are the resultant forces caused by gravity and lateral loads, respectively; $F_{\text {lim, }, k}=R_{k}-F_{k}$ is the limit action effect that is caused by episodic lateral force in limit state of joint core (Fig. 4). 


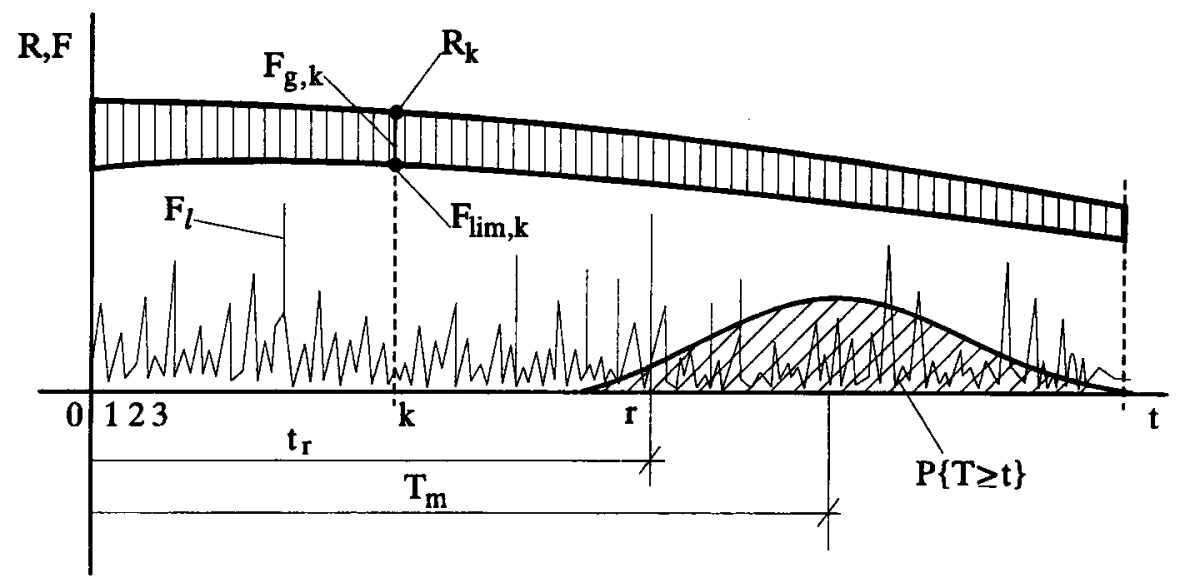

Fig. 4. Dynamic model for the estimation of structural safety of a member by method of random limit action effects

The resistance $R_{k}$ evaluates a gradual decrease in compression strength of strut member due to its instantaneous overloading, stress reversals and concrete cracking. The resistance $\mathbf{R}_{k}$ is a fixed random function, because its numerical value is random only at the beginning of a stochastic sequence, while in other cuts this value changes in accordance with a determinate law.

The percentage coefficient of variation is $5 \%$ for dead loads and $10 . . .30 \%$ for long duration and variable in time loads [7]. The normal law is applicable to action effects $F_{\mathrm{gk}}$ caused by these loads and concrete resistance $\mathbf{R}_{\mathbf{k}}$. Therefore, the probabilistic distribution law of onemodel limit action effect $F_{\text {lim, } k}=R_{k}-F_{g k}$ is close to the normal one and its value may be expressed by the formula:

$$
F_{\lim , k}=R_{m k}-F_{g m k}-\beta_{1}\left(\mathrm{~s}^{2} R_{k}+\mathrm{s}^{2} F_{g k}\right)^{1 / 2}
$$

Here $R_{m k}, s^{2} R_{k}$ and $F_{g m k}, s^{2} F_{g k}$ are the estimates of probability distribution of strut resistance and compressive force; $\beta_{1} \approx 0.95$ is the relative deviation of vector $R_{k}$ and $\mathrm{F}_{\mathrm{gk}}$ values from their means.

The law of distribution density of probability of extreme lateral loads, for instance, annual extreme wind values, are close to Gumbell [7] and Fisher - Tippet one with the coefficient of variation equal to $30 . .45 \%[9$, 10].

According to the method of limit random effects [7], an analysis sequence consists of $r$ stochastically independent cuts, where $r$ is the reiteration number of an episodic peal load.
The analysis of long-term safety of slab-wall joint cores may be based on the compound Poisson - Gumbell distribution law. The long-term safety index is

$$
\mathbf{P}\{T \geq t\}=\exp \left[-\sum_{k=1}^{r} \exp \left(\frac{a-F_{\mathrm{lim}, k}}{b}\right)\right] .
$$

Here $a$ and $b$ are the parameters of the extreme distribution of an episodic action effect. The parameters $\quad b=$ $\left(s^{2} F_{l k} / 1.645\right)^{1 / 2}$ and $a=F_{l m, k}-0.5776 b$, where $F_{l m, k}$ and $s^{2} F_{1 k}$ are the mean and variance of extreme action effect caused by lateral load. Therefore, the equation (62) can be written in the form:

$\mathbf{P}\{T \geq t\}=\exp \left[-\sum_{k=1}^{r} \exp \left(\frac{F_{l m, k}-F_{\text {lim, } k}}{0.78 \mathrm{~s} F_{l k}}-0.5776\right)\right]$

where $r=t_{r}$ in years; $s_{1 k}$ is the standard of probability distribution of the action effect $F_{1 k}$.

If the member resistance doesn't change in course of time, the analysis of its structural safety is simplified, because the long-term safety index is

$\mathbf{P}\{T \geq t\}=\exp \left[-r \exp \left(\frac{F_{l m}-F_{\mathrm{lim}}}{0.78 \mathrm{~s} F_{l}}-0.5776\right)\right]$.

\section{Conclusions}

The proposed simple method of limit random action effects allows to estimate the long-term structural safety of joint core of cast-in-situ reinforced concrete slab and wall connections subjected to gravity and episodic outplane lateral loads. This method evaluates the decrease of joint core resistance due to its random instantaneous 
overloading, stress reversals and by concrete strut cracking.

The structural safety indices belong to the main parameters characterizing reliability and cost of frameless reinforced concrete buildings subjected to large lateral loading.

\section{References}

1. Recommendations for single Design of Beam-Column Joints in Monolithic Reinforced Concrete Structures (reported by ACI - ASCE Committee 352) // Journal of the ACI, May-June 1985, No. 3, p. 266-283.

2. A. Kudzys, O. Joh, Y. Goto, A. Kitano. Behaviour of reinforced concrete interior and exterior wall-slab connections under lateral out-plane loading // Proccedings of the Japan Concrete Institute, Vol.17, No.2, pp. 628-633, Hiroshima (Japan), 1995.

3. J. O. Jirsa, N. W. Hanson. Recommendations for Design of Beam-Column Joints in Monolithic Reinforced Concrete Structures // Journal of the ACI, July 1976, p. 375-393.

4. Ant. Kudzys. Probability Estimation of Reliability and Durability of Reinforced Concrete Structures. Vilnius, 1992. $144 \mathrm{p}$.

5. E. Rosenblueth. Safety and Structural Design // Reinforced Concrete Engineering, Vol. 1, Materials, Structural Elements, Safety, New York, John Wiley and Sons, 1974, p.

6. Joints of Reinforced Concrete Structures. Collected Articles. Moscow: Stroyizdat, 1981. 89 p.

7. Ant. Kudzys, V. Vaitkevičius. Structural Safety of Welded Steel Structures // Strength, Durability and Stability of Materials and Structures, International Conference, September 18-20, 1996, Kaunas, Lithuania, p.

8. S.-T. Quek, H.-F. Cheong. Prediction of Extreme 3-sec. Gusts Accounting for Seasonal Effects // Structural Safety, v. 11, No. 2, 1992, p. 121-129.

9. N. B. Hutcheon, G. O. P. Handegord. Building Science for a Cold Climate. National Research Council Canada, 1995, p. 233-261.

10. Пособие по проектированию стальных конструкций. СНиП II-23-81. Москва, 1989. 150 с.

\section{GELŽBETONINIŲ PASTATỤ, KURIUOS VEIKIA VERTIKALIOSIOS IR HORIZONTALIOSIOS APKROVOS, STIPRUMAS IR PATIKIMUMAS}

\section{Alg. Kudzys}

\section{Santrauka}

Straipsnyje nagrinejamas vertikaliomis ir atsitiktinemis ar epizodinèmis horizontaliomis apkrovomis veikiamy gelžbetoninių sienų ir perdangos plokščụ sandūru itempimų büvis ir tikimybinis saugis. Analizuojamas monolitinio ir surenkamojo-monolitinio mazgo darbas ivvertinant gniuždomos betoninès prizmès būklę susiformavus ịstrižiems plyšiams. Išskiriamos sienų ir plokščių sandūros mazge veikiančios gniuždomosios jègos, sukeltos atskirai vertikalių ir horizontalių poveikių. Pateikiami mazgo ir jame susiformavusios ịstrižos betoninès prizmès ịrąžy statistiniai parametrai, ịvertinant medžiagu fizinių-mechaniniu savybiu ir apkrovy variacijas. Nagrinèjamas ryšys tarp betoninès prizmès pločio ir mazge veikiančių vidaus jègų peties kitimo.

Betoninio mazgo saugio indekso reikšmès skaičiavimui siūlomas ribinių atsitiktinių irąžy̨ metodas. Šis metodas leidžia įvertinti daugiaaukščio pastato sandūros mazgo stiprumo sumažejimą dèl atsitiktiniu nuolatiniu perkrovimy, įrą̌̆ krypties kitimo bei betono supleišèjimo. Struktūrinio saugio indeksas pateikiamas kaip vienas iš pagrindinių parametrų, apibūdinančių gelžbetoninių pastatų, veikiamų didelèmis horizontaliomis apkrovomis, patikimumą ir kainą.

İteikta 19961127 